\title{
GREEN LOGISTICS AND CLEAN ENERGY IMPLEMENTATION - STRATEGIES AND METHODS -
}

\author{
Anita Vasileva, Kristina Jakimovska \\ Faculty of Mechanical Engineering, "Ss. Cyril and Methodius" University in Skopje, \\ P.O. Box 464, MK-1001 Skopje, Republic of North Macedonia \\ anita_vasileva@yahoo.com
}

\begin{abstract}
A b s t r a c t: Logistics is no longer just a word for organization and optimization. What is new is, on the one hand, cost, smart technology and, on the other hand, minimizing and reducing waste, gases, vibrations and investment in eco-friendly solutions. As a result of the pollution, everything that is connected with ecology and efficiency mean not only a reduction of $\mathrm{CO}_{2}$ emissions, but also recycling and cost savings. Accordingly, the basic methods and principles of green logistics and clean energy and their relationship to logistics offered optimizing the cost for long term in combination with eco-friendly solutions. Related to the idea of using green logistics and clean energy, this paper discusses strategies, methods of implementation and an analysis of the various options.
\end{abstract}

Key words: green logistics; clean energy; optimization; eco-friendly

\section{СТРАТЕГИИ И МЕТОДИ ЗА ИМПЛЕМЕНТАЦИЈА НА „ЗЕЛЕНА“ ЛОГИСТИКА И „ЧИСТА“ ЕНЕРГИЈА}

\begin{abstract}
А п с т р а к т: Логистиката не е повеќе само збор поврзан со организација и оптимизација. Она што е ново, од една страна, е паметната технологија и, од друга страна, намалувањето на отпадот, гасовите, вибрациите и инвестирањето во еколошки решенија. Како резултат на загаденоста, сѐ што е поврзано со екологија и ефикасност не значи само намалување на емисиите на $\mathrm{CO}_{2}$, но значи и рециклирање и намалување на трошоците. Според тоа, основните методи и принципи на 'зелената' логистика и 'чистата' енергија и нивната поврзаност со логистиката воопшто нудат оптимизација на трошоците на подолгорочен план во комбинација со еколошки предлози. Поврзано со идејата за користење на 'зелената' логистика и 'чистата' енегија, овој труд ги дискутира стратегиите и методите на имплементацијата и ги анализира различните опции.
\end{abstract}

Клучни зборови: ‘зелена’ логистика; ‘чиста’ енергија; оптимизација; екологија

\section{INTRODUCTION}

The logistics processes affect almost every sphere of human activity. Till now, all areas of logistics have a significant impact on the final price. Getting the right goods or services to the right place, at the right time and in the desired condition at the lowest cost while having the highest return on investment, was the well known mission of logistics [1]. Nowadays, good logistics management seizes any opportunity that could be used to increase the recycling process $[1,2]$. Rationalization the time needed for logistics processes and rational use of waste materials and are two different ways in which they can act. Modern, futuristic industries in the world, can partially use eco-friendly solutions, or entirely self-produce the necessary energy by using renewable energy sources. This can be a perfect option to cut off emissions as well as energy costs. Several most trendy, smart and clean sources in the world are solar, biomass, and the wind. [3]. Due to the extensive capital investment, self-production of energy in most of the industries is not a costefficient one. Choosing an affordable way to selfproduce energy is a hard task and a big risk in our country. Solar panels are an expensive investment 
for North Macedonian industry because they usually require about 15-20 years of payback. However, a decision for renewable investment requires a large analysis of payback investment, before managers make a green decision [3]. The investment in energy self-production is a good choice but only for big industries and if governments provide the necessary incentives. Governments' politics and power plays a vital role in green energy generation [3]. On the other hand, the aspect that focuses on the internal factors of the green industry such as heating, lighting, air changes and mechanical handling equipment is named clean energy technology. Figure 1. illustrates percentages only of energy consumption in the warehouse. Figure 2 shows U.S. electricity consumption by market sector in 2014 (Source: EPSA Side Case, 2014) [14].

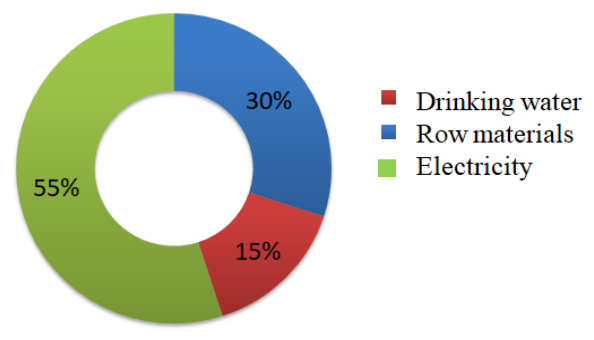

Fig. 1. Energy consumption in the warehouse (Source: Fire Foundation, 2013)

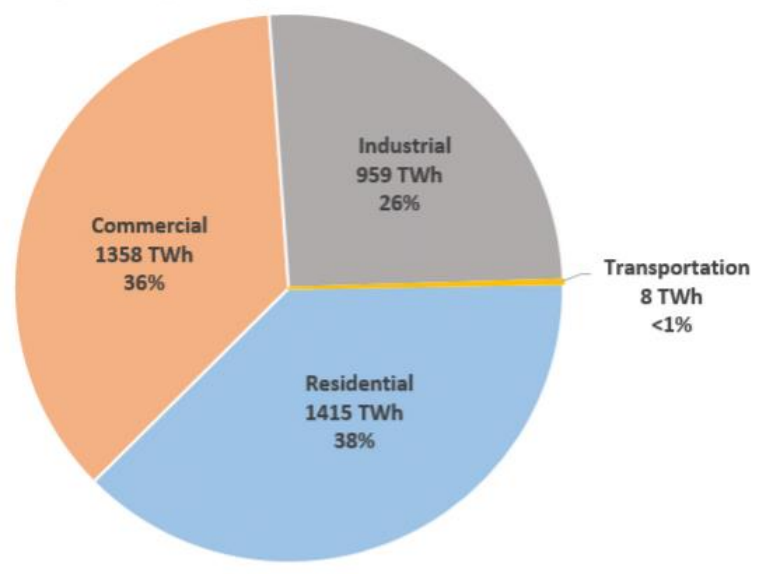

Fig. 2. U.S. electricity consumption by market sector, 2014 (Source: EPSA Side Case, 2014)

The main goal of clean energy technology is to be implemented in any industry without expensive investment. Implementation of clean energy is to make the roof and window design more able to aid conservation of sunlight and to use night LED lighting, in other words. On the Figure 3. is shown investment in clean energy worldwide from 2014 to 2018. (Source: Statista, 2020)

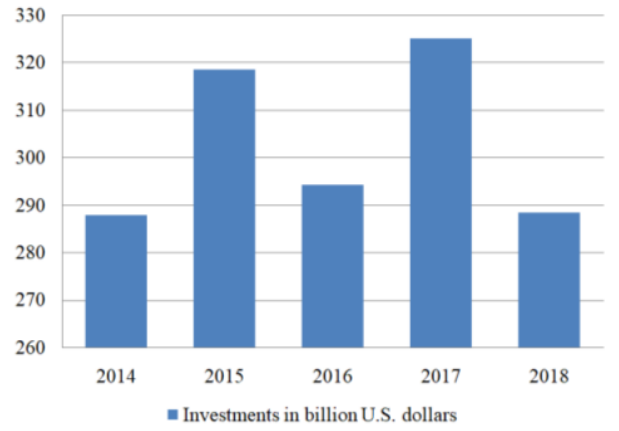

Fig. 3. Investment in clean energy worldwide from 2014 to 2018 (Source: Statista, 2020)

This paper will be splitted in three parts. The first part of this paper presents information about green logistics and clean energy as well as a new approach to achieve the goals of eco- friendly solutions. The second part shows methods and solutions for implementation and the last part will be analysis and discussion.

\section{IMPLEMENTATION OF GREEN LOGISTCS AND CLEAN ENERGY}

The industry affects air quality and an increased carbon dioxide emission from the energy sector. Research indicates that one of the worldwide, top contributors to lung cancer is the diesel trucks used in the warehousing industry $[5,6]$.

On the Figure 4 is shown death rates from air pollution in the World (Source: Our World in Data).

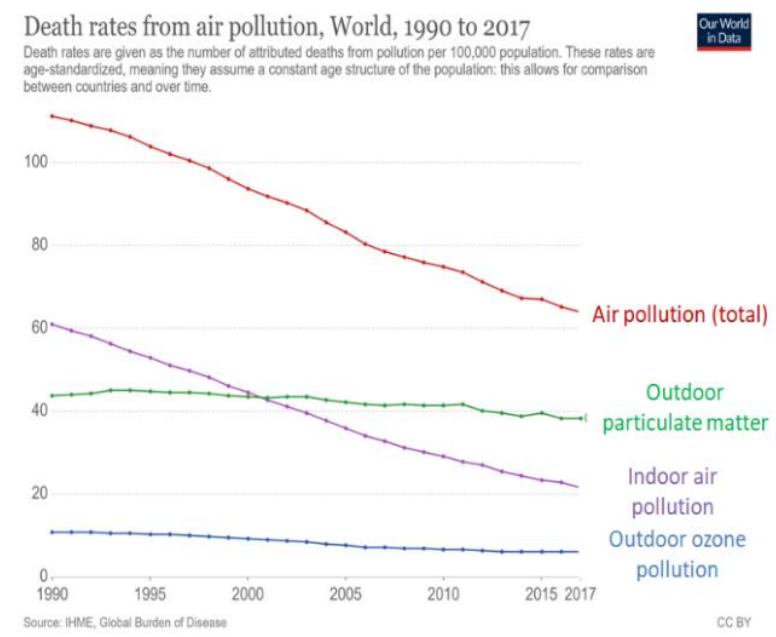

Fig. 4. Death rates from air pollution, World, 1990 to 2017 (Source: Our World In Data, 2017)

Depending on the function and the nature of the industry, local weather, design and in-house activities, each industry has different requirements. 
The primary sources of energy for heating/cooling systems in the industry come from gas, fuel energy, and electricity $[4,5]$. Buildings are a serious contribution to global emissions and need to be a part in efforts to decrease them. Electricity demand in the building sector is predicted to grow by $70 \%$ by 2050, even with implemented improvements in appliance efficiency [7].

The REmap Case considers deployment of highly efficient appliances, involving smart systems with modern controls for lighting and heating, improved heating and cooling systems, better insulation etc. [7]. Statistics analysis predict that industry must rise the implementation of renewable energy in to $48 \%$ by 2050 [7]. Under the energy transition, electricity should meet $41 \%$ of industry's energy needs by 2050 [7]. In percentage terms, the studies predict that the largest increase will be in use of solar panels for low-temperature processes [7].

There is a large potential to implement efficiency and eco-friendly solutions in the industrial sector. Most of the upgrades can be made in countries which are in developing and economics in transition. Precisly, the sector can: upgrade process efficiency, adopt management solutions, introduce highly efficient devices and develop material recycling [7].

For small businesses, the first change to implement for clean and green logistics is to optimize the routes they take. Instead of picking products for multiple orders, they can handle one order at a time: moving to the right shelf, at the right time, picking the product etc. Some analyses, calculate the total picking time, and potential savings, using the bound cavities method, that can be, with adjustments, applied for other purposes in the industries [5].

\section{A SOLUTION METHODS}

There are lot of study methods for green supplier selection, but also there are researchers which calculate the pollution and after that select the right solution for implementation of green logistics and clean energy technology. In this paper will be illustrated one mathematical modeling of air pollutants and after that method for green supplier selection. On Fig. 5. is illustrated how long companies (supply chain) implement the green supply chain / green logistics.

The first thing that researchers tries to do is to find way to calculate the pollutions and the sources of pollutions.

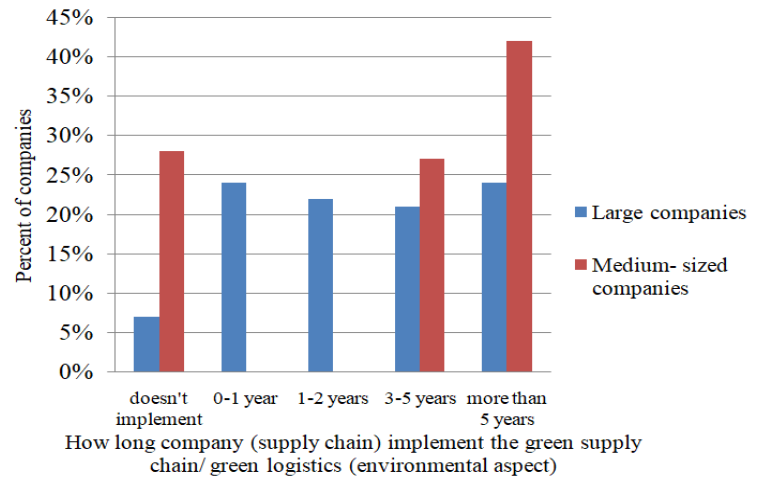

Fig. 5. Number of companies with environmental certifications vs. period of implementing of green supply chain (Poland, 2018) [11]

The statistical model is to analyze past monitored air quality data which are divided into linear and non-linear models. Linear models as Multiple Linear Regression (MLR) can be used to make a relationship between air pollutants and meteorological variables [8].

$$
Y=b_{1}+b_{2} X_{2}+\ldots+b_{k} X_{k}+e,
$$

where:

$Y$ - dependent variable;

$X_{2}, \ldots X_{\mathrm{k}}-$ independent variables;

$b_{1}, b_{2}, \ldots b_{\mathrm{k}}$ - linear regression parameters,

$e-$ an estimated error term.

The purpose of regression modeling is to estimate the $b_{1}, b_{2}, \ldots, b_{\mathrm{k}}$, which can be made using minimum square error technique.

The Eq. (1) can also be written as:

$$
Y=X b+e,
$$

where:

$$
\begin{aligned}
Y & =\left[\begin{array}{l}
Y_{1} \\
Y_{2} \\
\cdot \\
\cdot \\
Y_{n}
\end{array}\right], \quad X=\left[\begin{array}{cc}
x_{21} x_{31 \ldots} & x_{k 1} \\
x_{2 n} x_{3 n} \ldots & x_{k n}
\end{array}\right], \\
b & =\left[\begin{array}{l}
b_{1} \\
b_{2} \\
\cdot \\
\cdot \\
\cdot \\
b_{k}
\end{array}\right], \quad e=\left[\begin{array}{l}
e_{1} \\
e_{2} \\
\cdot \\
\cdot \\
\cdot \\
e_{n}
\end{array}\right]
\end{aligned}
$$

$Y$ is an $n \times 1$;

$X$ is an $n \times k$;

$b$ is an $k \times 1$;

$e$ is an $n \times 1$ matrix. [8] 
TOPSIS (Technique for Order Preference by Similarity to Ideal Solution), one of the many classical MCDM methods, is based on the concept to choose alternatives which have the shortest distance from the positive ideal solution (PIS) and the farthest from the negative ideal solution (NIS) [9].

For presenting the MCDM methods, as one of the possible ways of ranking the green solutions, in this paper are chosen three alternatives (A1, A2, A3) and four evaluating criteria $(\mathrm{C} 1, \mathrm{C} 2, \mathrm{C} 3, \mathrm{C} 4)$. For example:

\section{A1: clean energy, \\ A2: smart technology, \\ A3: self-produce energy.}

The last step in implementation of TOPSIS method is calculation of performance score and making rank of the $P_{i}$ value (Table 1). From the rank, we can conclude that the ideal option, in our example, is alternative no. 2 (smart technology).

\section{T a b l e 1}

Rank of the Pi value

\begin{tabular}{lllc}
\hline $\mathrm{S}^{+}$ & $\mathrm{S}^{-}$ & $\mathrm{Pi}$ & $\mathrm{Rank}$ \\
\hline 0.00978 & 0.0377 & 0.278 & 3 \\
0.03770 & 0.099 & 0.724 & 1 \\
0.05040 & 0.065 & 0.567 & 2 \\
\hline
\end{tabular}

This is a simple example of how we can make a decision on what is the best option for investment in our situation. In a real situation we can put more criteria, and by using the MCDM methods, to select the best option for us. This is a simple example of how to make a decision on what is the best option for investment in some situations. In a real situation we can put more criteria, and by using the MCDM methods, to select the best option for us. Figure 6 is an algorithm that illustrates on which principle is working multiple-criteria decision-making (MCDM),

Most research papers for optimization the logistics processes are using the Genetics algorithms. The goal is by using different types of crossover one of them to give the optimal solution. Crossover is a genetic operator which combines two chromosomes to produce a new chromosome or offspring. The main idea behind crossover is that the offspring may be better than both of the producers if it takes the best characteristics from each of them [10].

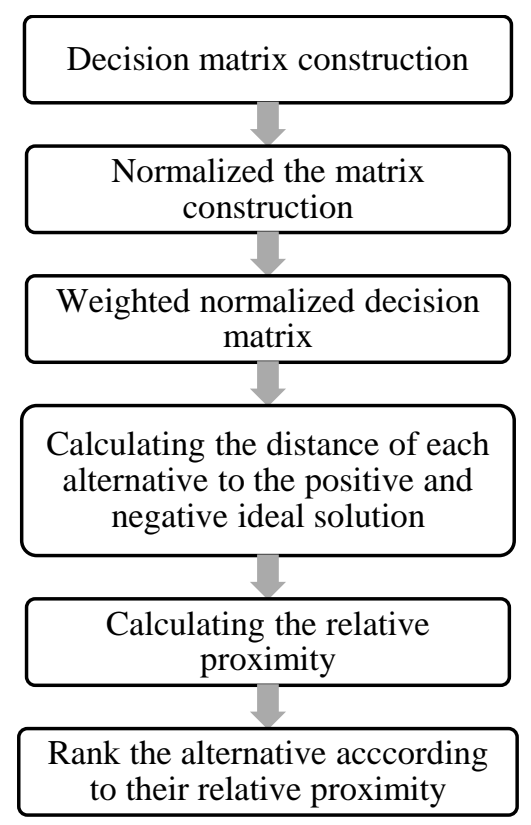

Fig. 6. MCDM algorithm

The crossover type that is on Figures 7 and 8 uses some probability known as a fixed mixing ratio, it decides which producer will contribute to the gene level rather than the segment level. If the mixing ratio is 0.5 , approximately half of the genes in the offspring will come from producer 1 and the other half will come from producer 2 .

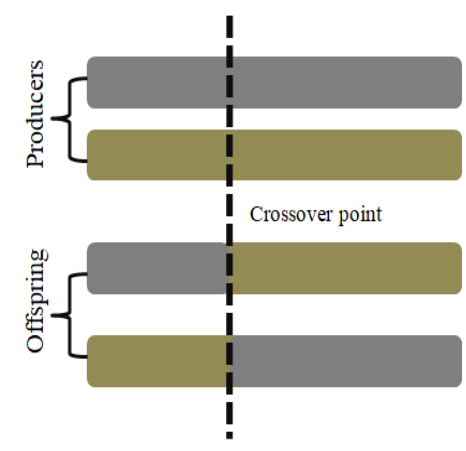

Fig. 7. One point crossover representation

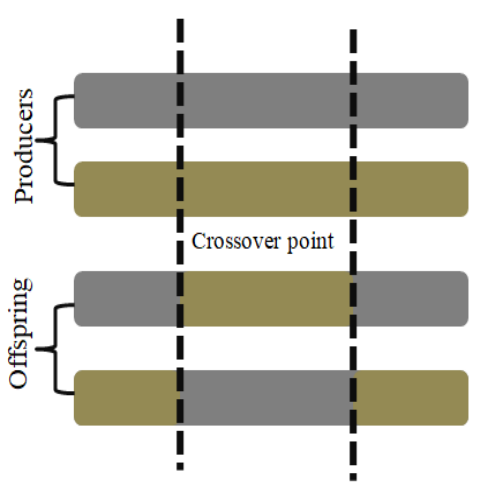

Fig. 8. Two points crossover representation 
The main idea for the crossovers shown on Figures 9 and 10 are to change the length of the new offsprings. so each producer has a different crossover point [10].

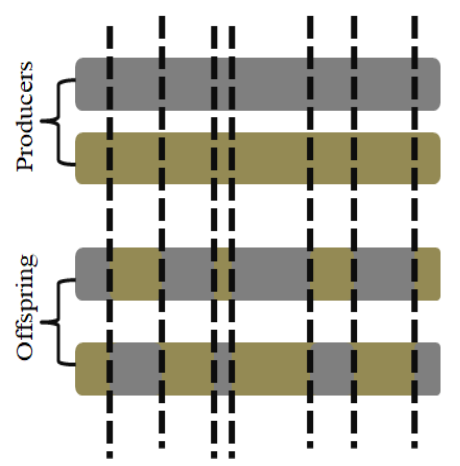

Fig. 9. Uniform crossover representation

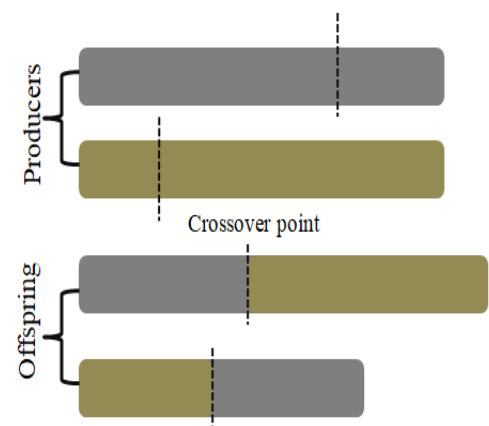

Fig. 10. Cut and spice crossover representation

\section{CONCLUSION}

To date, the industry sector has been the biggest laggard with focus to the energy transition. In 2015 renewables were only around 7\% of industry's direct energy use (Figure 11) [7]. Analysis shows that the industrial sector is the second-largest emitter of $\mathrm{CO}_{2}$ [7]. The results demonstrate that chemical, petrochemical and steel are among the largest emitters, because they employ energy intensive and high temperature processes that are difficult to decarbonize. Nevertheless, not only large companies are pollutants. The results show medium and small companies sometimes have nearly the same percentages as large companies. In conclusion it means that everyone needs to be involved in eco-friendly solutions. The research outcome can provide insightful information about avaiable methods for choosing the best option for optimisation the rutes or calucate the pollutants and after that to make analysis about it. By applying the appropriate mathematical models and criteria, the results showed where it is advisable to invest. These data can help to make a global picture and to keep track of the situation of logistics and energy efficiency and as well as to enable better decision- making a process in the future. Although the main direction is to implement energy self-production, this paper suggested using different efficient types, especially clean energy.

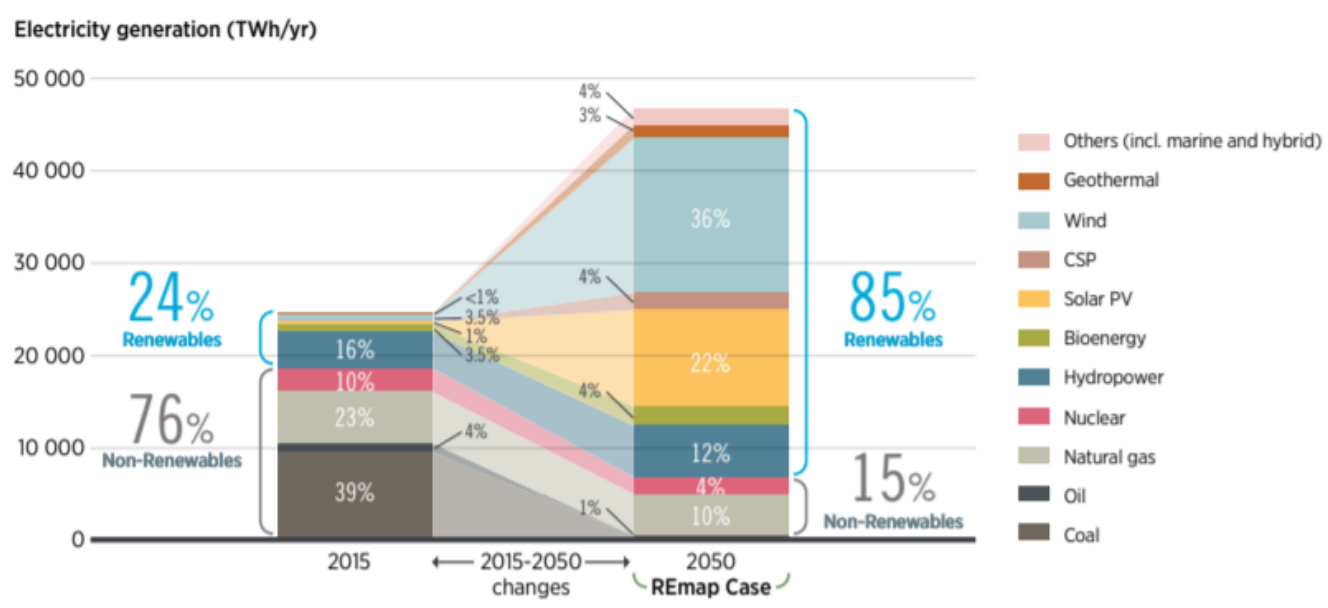

Fig.11. The rising importance of solar and wind energy in the power sector. Breakdown of electricity generation, by source (TWh/yr) [7]

\section{REFERENCES}

[1] Pulevska Ivanovska, L.: Logistics/Supply Chain Management, "Ss. Cyril and Methodius" University in Skopje, Faculty of Economics, Skopje, 2009.
[2] McKinnon, A., Cullinane, S., Browne, M., Whiteing, A.: Green logistics, Improving the environmental sustainability of logistics, Journal of Transport Geography, Vol. 20, Issue. 1, pp. 89-90 (2012). ISBN 9780749456788

[3] Richards, G., Riding, C.: Warehouse Management: A Complete Guide to Improving Efficiency and Minimizing 
Costs in the Modern Warehouse, Second edition, Kogan, (June 28, 2014), London, ISBN-13: 978-0749469344.

[4] Bhattacharjee, K.: Green supply chain management challenges and opportunities, Asian Journal of Technology \& Management Research, Vol. 5, Issue, 1, pp. 14-19 (Jan - Jun, 2015).

[5] Bouhlal, A.: Green logistics, 9th International Conference on Traffic Science ICTS 2005, Portorož, Slovenia, November 2005.

[6] Arvis, J.-F., Ojala, L., Wiederer, Ch.: Connecting to Compete 2018 Trade Logistics in the Global Economy the 2018 Edition of the Logistics Performance Index (LPI), The World Bank, Turku School of Economics, University of Turku, 2018, DOI: 10.1596/29971.

[7] Global Energy Transformation: A Roadmap to 2050, International Renewable Energy Agency (IRENA), 2018.

[8] Goyal, P,, Kumar, A,: Mathematical Modeling of Air Pollutants: An Application to Indian Urban City, In Tech Open, 2011.
[9] Celik, E,. Erdogan, M,. Gumus, A, T.: An extended fuzzy TOPSIS-GRA method based on different separation measures for green logistics service provider selection, Int. J. Environ. Sci. Technol. Vol. 13, pp. 1377-1392 (2016).

[10] Tzu-Liang, B., Tseng. Ituarte-Villarreal, Gabriela. C. Ho, Johnny. Huang, Chun-Che: Optimization of green logistics using genetic algorithm, Proceedings of the 2015 Industrial and Systems Engineering Research Conference, S. Cetinkaya and J. K. Ryan (eds.), pp. 3111-3120. 2015.

[11] Tundys, B.. Wiśniewski, T.: The Selected method and tools for performance measurement in the green supply chain - Survey analysis in Poland, Sustainability, Vol. 10, No. 2, pp. 549 (2018).

[12] Schwartz, L.. Wei, M.. Morrow, W.: Energy Analysis and Environmental Impacts Division Lawrence Berkeley National Laboratory, Electricity and Uses, Energy Efficiency, and Distributed Energy Resources Baseline, Berkeley LAB, 2017. 